\title{
Mice lacking pituitary tumor transforming gene show elevated exposure of DGalNAc carbohydrate determinants
}

\author{
O. Yu. Varyvoda, Yu. Z. Filyak', A. D. Lutsyk, R. S. Stoika ${ }^{1}$ \\ Danylo Halytsky Lviv National Medical University \\ 69, Pekarska str., Lviv, Ukraine, 79010 \\ ${ }^{1}$ Institute of Cell Biology, NAS of Ukraine \\ 14/16, Drahomanov Str., Lviv, Ukraine, 79005 \\ lutsyk@meduniv.lviv.ua
}

\begin{abstract}
Aim. To investigate the influence of pituitary tumor transforming gene (pttg-1) knockout on glycome of parenchimal organs by means of lectin histochemistry. Methods. DGalNAc, DGlcNAc, NeuNAc carbohydrate determinants were labelled with soybean agglutinin (SBA) and wheat germ agglutinin (WGA), conjugated to peroxidase, with subsequent visualization of the lectin-binding sites with diaminobenzidine. The testes and kidneys of murine strain BL6/C57 with the pttg-1 gene knockout (PTTG-KO) were compared to the wild type (PTTG-WT) animals, both groups 1 month of age. Results. Knockout of the pttg-1 gene was accompanied by enhanced exposure of the DGalNAc sugar residues within the Golgi complex of secondary spermatocytes, in a brush border of renal tubules and on the lumenal surface of collecting ducts. Conclusions. This study suggests that knockout of the pttg-1 gene may lead to the changes in carbohydrate processing in mammalian organism.
\end{abstract}

Keywords: knockout of pttg-1 gene, glycoconjugate processing, lectin histochemistry.

Introduction. Pituitary tumor transforming gene was first revealed in tumor cells of rat pituitary gland in 1997 [1]. In 1999 it was described for humans [2]. At present the increase in expression of this gene and the level of production of securin protein, coded by it, is considered to be one of the most reliable signs of [the] adenoma development in the pituitary gland of humans and mammals [3]. Besides, it was established that increased expression of PTTG protein is remarkable for tumors of other localization - pituitary gland, mammary gland, and rectum [4].

In order to deepen the knowledge about the physiological role of $p t t g-1$ in the organism, the murine line with the absence (knockout) of this gene was cultivated [5]. At preserved fertility such mice (pttgKO) are characterized by hyperplasia of thymus along with the hypoplasia of spleen and testes as well as with thrombocytopenia [5]. Later some data were obtained

(C) Institute of Molecular Biology and Genetics, NAS of Ukraine, 2012 about the inhibition of erythropoiesis processes in them [6]. The proteome technology allowed identifying 18 proteins, the expression of which was different in murine lymphocytes with pttg-1 gene knockout, that indicates the damage of key links in immune defense [3]. It was also shown that the gene knockout caused the impairment of murine spermatogenesis [2].

The investigation of the mechanism of action of the pttg- 1 encoded securin protein revealed the capability of the latter to prevent premature diversion of sister chromatids in the anaphase of mitosis due to inhibition of the separase activity as well as to play some part in the provision for the stability of chromosomes [2, 5]. It is believed that due to these properties securin participates in the regulation of the cellular cycle, DNA reparation and apoptosis [3].

The carbohydrates in the composition of glycoproteins of cellular surface are known to perform both structural and signaling functions. In particular, they 
are essential for intercellular interactions as well as for the recognition of certain types of cells (for in- stance, apoptotic ones) by immunocompetent cells, performing clearance in the organism. The anatomic study of mice, lacking pttg-1, revealed a considerably decreased weight of spleen and increased weight of thymus which allows supposing autoimmune state in these animals. Some indices of the similar state were determined by us in another investigation [7]. Besides, we revealed the desialylation of glycoconjugates by membrane neuraminidases on the surface of cells, which are at the stage of apoptosis; it results in an increase in the level of exposure of galactose and mannose residues [8]. It is known that membrane vesicles, formed on the surface of apoptotic cells, may originate from the plasmatic or endoplasmatic reticulum membranes, and the latter are remarkable for higher immunogenicity and better recognition by macrophages [9].

Up-to-now the specificities of glycoma of the surface of cells from different tissues and organs of mice, lacking pttg-1, have not been studied. Taking the abovementioned into consideration, we assumed it reasonable to check whether possible changes of glycoma may cause some impairments in animals lacking pttg-1 while their reproductive function is preserved. It was previously shown that the level of expression of pttg-1 is considerably higher in the cells of male reproductive system $[1,2]$.

The current work is aimed at using the methods of lectin histochemistry to study the influence of pttg-1 deficiency on glycoma of some murine parenchymal organs.

Materials and Methods. Animals. Mice lacking pttg-1 were obtained from the Scientific Research Institute of the Cedar Sinai Medical Center (USA) in the framework of the agreement on scientific cooperation. Gene knockout was simulated in BL6/C57 line mice. The presence/absence of $p t t g-1$ was identified using polymerase chain reaction (PCR) with primers, specific to the sequence of $p t t g-1$ and to the insert, built into the murine genome instead of the sense region of pttg-1.

Animal samples. The morpho-histochemical characteristics of liver, kidneys, testes and lungs of five mice lacking pttg-1 (pttg-KO) and five wild type mice (pttg-WT), both groups 1 month of age, which were kept in the vivarium conditions of the Institute of Cell Biology, NAS of Ukraine (L'viv). All the work with animals was performed with the adherence to the main provisions of the Convention of the European Council on the protection of vertebrates which are used in experiments and for other scientific purposes, dated March 18, 1986, the Directive of the Ministry of Health of Ukraine No. 281, dated November 01, 2000.

Euthanasia was administered to mice by overdose of diethyl ether. Histological material was fixed in $4 \%$ solution of neutral buffered formalin, dehydrated, contracted, and poured into paraplast using the standard method. In order to study general morphology the $7 \mu \mathrm{m}$ [thick] cuts were stained with hematoxylin and eosine.

Lectin histochemistry. To study carbohydrate determinants of testes and kidneys - the organs, morphological characteristics of which are changed the most, compared to the control - we used soybean agglutinin (SBA, specific to DGalNAc - N-acetyl-D-galactosamine) and wheat germ agglutinin (WGA, specific to residues of DGlcNAc - N-acetyl-D-glucosamine and Neu- NAc - N-acetyl-neuraminic (sialic) acid) [10, 11]. Lectins were purified and conjugated with horseradish peroxidase by Dr. Sci. in Pharmacology V. O. Antonyuk (Lectinotest Laboratory, Ukraine).

Dewaxed cuts were incubated for $45 \mathrm{~min}$ at room temperature with lectin-peroxidase conjugate (concentration of $10-25 \mu \mathrm{g} / \mathrm{ml}$ ) in the buffered physiological solution ( $\mathrm{pH}$ 7.4). The localization of lectin receptors was visualized by $0.05 \%$ solution of diaminobensidine tetrahydrochloride (Sigma, USA) in presence of $0.015 \%$ $\mathrm{H}_{2} \mathrm{O}_{2}$. The method of lectin histochemistry as well as the methods of controlling specificity of histochemical reactions are described in more detail in the monograph [11].

The study and photographic recording of preparations were performed using Carl Zeiss microscope (KM 470600-9901), completed with digital photo- eyeglass CCD Delta Optical (Pro-MicroScan 58222 M Pixels).

Results and Discussion. While analyzing histological preparations, stained with hematoxylin and eosine, the following changes were revealed:

Lungs. In the macroscopic review: covered with serous coat, of pink color, right and left lungs, divided into three and two parts, respectively. In the microscopic review: the organ parenchyma of the organ is composed of alveoli and alveolar pathways, alveoli are divided by interalveolar membranes, inconsiderably increased due to narcosis. There were 
no significant morphological differences revealed between the lungs of experimental (pttg-KO) and control (pttg-WT) groups.

Liver. In the macroscopic review: of triangular shape, of brown color, elastic, without pathological formations, covered with a connective tissue membrane. In the microscopic review: the parenchyma of the organ is composed of particles, the cytoplasm of hepatocytes is homogeneous. Liver triads (inter-particle artery, vein and bile duct) are clearly visualized. There were no statistically significant morphological differences revealed between the preparations of liver of mice in the experimental and control groups.

Testes. In the macroscopic review: binate organs, of elastic consistency, covered with connective tissue capsule. In the microscopic review: the parenchyma is divided by connective tissue membranes (septums) into parts, there are clearly visualized convoluted seminiferous tubules, covered with the basal membrane, along the perimeter of these tubules there are hemocapillaries with the layers of connective tissue with localized Leidig cells. The inner content of convoluted seminiferous tubules is composed of two cell populations: nurse cells (Sertoli cells) and spermatogenic cells (Fig. 1, a, see the insert).

The convoluted seminiferous tubules of the experimental group mice (pttg-KO) demonstrated damaged structure and topography of Sertoli cells, a decrease in the populations of spermatogenic cells, destroyed syncytial complexes between them (Fig. 1, $\mathrm{b}$, see the insert) which testifies to the disorder of spermatogenesis processes. The results, obtained by us, complement the data of other authors [5] who registered testes hypoplasia in mice lacking pttg-1 and possible disorders of spermatogenesis.

Kidneys. In the macroscopic review: binate, bean-shaped structure, covered with fibrous capsule. In the microscopic review: renal cortex and renal medulla are visualized, renal cortex in the shape of Bertin columns divides the medulla into renal pyramids. The kidney parenchyma is formed by renal corpuscles, convoluted and straight seminiferous tubules and collecting ducts. A renal corpuscle is formed by a Malpighian glomerulus and a nephron capsule (Shumlyansky-Bowman's capsule) (Fig. 2, a, see the insert). The kidneys of animals in pttg-KO group demonstrated the induration of capillaries of Malpighian glomerulus of the renal corpuscle and the enlargement of the urinary space of the nephron capsule (Fig. 2, b, see the insert) which may testify to the enhancement of the ultrafiltration processes of the primary urine.

Therefore, no specific changes were revealed in lungs and liver of one month-old mice, lacking pttg-1, by general morphological methods. In the testes of experimental animals the modifications were identified in the composition of convoluted seminiferous tubules which were revealed as damaged structure and topography of Sertoli cells, a decrease in the population of spermatogenic cells and destruction of syncytial complexes between them. In kidneys the absence of pttg-1 was combined with the induction of hemocapillaries of Malpighian glomerulus and the enlargement of the urinary space of the renal corpuscles.

Results of lectin histochemistry. The glycopolymers of testes and kidneys - the organs which demonstrated the highest susceptibility to pttg-1 knockout - were studied using soybean agglutinin (SBA) and wheat germ agglutinin (WGA).

Testes. In the convoluted seminiferous tubules of the control group mice the soybeans agglutinins are mainly concentrated in the zone of Golgi complex of secondary spermatocytes on the background of practically absolute areactivity of Sertoli cells, other subpopulations of spermatogenic and myoid cells (Fig. 1, c; Fig. 3, a, see the insert). The revealed selectivity of binding soybean agglutinin is likely to be the reflection of active processing of glycopolymers (binding DGalNAc residues) in course of formation of acrosomal systems of sperm cells. The animals lacking pttg-1 demonstrated preserved SBA-reactivity of Golgi complex of secondary sperm cells (Fig. 1, d,); here the saturation of some convoluted seminiferous tubules with the lectin-positive cells exceeded the control indices; the phenomena of disorganization of syncytial complexes of spermatogenic cells were noted.

The receptors of WGA lectin in the control group animals were revealed in the composition of cytoplasmatic glycoconjugates of spermatogonii, plasmolemma of spermatogenic cells of different degree of maturity, tail zones of sperm cells (Fig. 1, e,). The mice, lacking pttg-1, demonstrate increased 
plasmolemma contouring of sperm cells in proximity to the lumen of convoluted seminiferous tubules, which is combined with the reduction in spermatogonia reactivity (Fig. 1, f); it testifies to the enhancement of glycosylation processes at last stages of spermatogenesis.

Taking into consideration the carbohydrate specificity of soy lectins and wheat germs it is possible to state that the absence of $p t t g-1$ is accompanied with the elevated exposure of DGalNAc and DGlcNAc carbohydrate determinants in structural components of testes. It is possible that the abovementioned phenomenon is one of the reasons for registered [5] phenomenon of preserving fertility animals, since, according to [13], DGalNAc and DGlcNAc residues play a significant role in the processes of mice fertilization.

Kidney. The mice of control group demonstrated localization of the SBA lectin receptors only in the composition of glycopolymers of lumenal surface of collecting renal ducts (Fig. 2, c). The knockout of pttg-1 is accompanied by increased lumen contouring of the mentioned ducts and by weak reactivity of the brush border of proximal tubules (Fig. 2, e,), which may testify to elevated exposure of the DGalNAc residues in the renal structures.

The receptors of WGA lectin in the control group mice were revealed on the lumenal surface of collecting renal ducts, filtration membrane of renal corpuscles and, though to the lesser degree, - in the composition of the brush border of proximal and distal tubules (Fig. 2, e; Fig. 3, b). No significant changes were revealed in the reactivity of renal structures with WGA lectin under the pttg-1 knockout (Fig. 2, f).

The investigations showed the elevated exposure of DGalNAc carbohydrate determinants in the Golgi complex of secondary spermatocytes and brush border of renal tubules of mice, lacking pttg-1 (Fig. 1, e; Fig. 2, e). Certainly, taking into consideration the only currently known function of the product of this gene, namely, the participation in the regulation of divergence of sister chromatids during mitosis [12], it is difficult to state that the abovementioned changes of carbohydrate determinants may directly result from pttg-1 deficiency. More plausible is the assumption about the mediated mechanism, which implies the activity of products of other genes, capable of changing their expression due to pttg-1 knockout. It is evident that more detailed answers to these questions may provide an in-depth analysis of proteome results, which we have obtained for lymphocytes of wild type mice and mice lacking pttg-1, [3].

The elevated exposure of the DGalNAc carbohydrate determinants in tissues is remarkable for both immature (embryonic) structures and many forms of pathology $[11,14,15]$. The results, obtained by us, complement these observations. Subterminal localization of the DGalNAc residues in the composition of oligosaccharide chains of O-glycans, notable for structural components of testes and kidneys of wild type mice (functional glycomics database: www.functionalglycomics.org), allows the assumption about incomplete nature of terminal stages of biopolymer glycosylation in mice, lacking pttg-1.

Conclusions. The investigations performed deepen current understanding of the physiological role of pttg-1, in particular, they demonstrate the change in processing hydrocarbon biopolymers in the organism in the absence of this gene. At the same time there is an open issue about intercellular signaling pathways and exogenous factors which enhance the activity of pttg-1 and, as a result, promote prerequisites for malignant transformation.

The data obtained allow recommending soybean agglutinin as a selective marker of Golgi complex (maturing acrosomal systems) of secondary spermatocytes and glycopolymers of lumenal surface and collecting renal tubules, and wheat germ agglutinin - as a marker of the filtration membrane of renal corpuscles of mice.

It is planned to extend the list of used agglutinins and the spectrum of investigated carbohydrate determinants to deepen the knowledge about the character of transformation of hydrocarbon biopolymers, caused by pttg-1 deficiency.

The authors would like to express their gratitude to Dr. S. Melmed (Cedar Sinai Medical Center, USA) for his help in obtaining mice lacking pttg-1; Olga Kanyuka and Sergiy Afanasiev - for their assistance in the work with laboratory animals. 


\section{О. Ю. Варивода, С. З. Філяк ${ }^{l}$ О. Д. Луцик, Р. С. Стойка ${ }^{I}$.}

Нокаут гена pttg у мишей супроводжується

підвищеним рівнем експонування вуглеводних детермінант DGalNAcDanylo Halytsky Lviv National Medical University

69, Pekarska str., Lviv, Ukraine, 79010

Львівський національний медичний університет імені Данила Галицького

Вул. Пекарська, 69, Львів, Україна, 79010

Інститут біології клітини НАН України

Вул. Драгоманова, 14/16, Львів, Україна, 79005

Summary

Мета. Дослідити вплив нокауту гена pttg-1 на гліком деяких паренхіматозних органів мишей, використавши для цьього засоби лектинової гістохімї. Методи. Вуглеводні детермінанти DGalNAc, DGlcNAc i NeuNAc виявляли за допомогою лектинів сої та зародків пшенииі, мічених пероксидазою хрону, з наступною візуалізацією діамінобензидином. Тест-об'єктами слугували яєчка та нирки мишей лінї BL6/C57 з нокаутом гена pttg-1 $і$ мишей дикого типу віком 1 місяиьь. Результати. Нокаут гена pttg-1 супроводжу- ється підвищеним експонуванням вуглеводних детермінант DGalNAc у складі комплексу Гольджі вторинних сперматоцчтів, щіточкової облямівки ниркових трубочок та на люменальній поверхні збірних ниркових проток. Висновки. Отримані результати свідчать про те, щчо відсутність гена pttg-1 може призвести до змін у процесингу вуглеводвмісних біополімерів в організмі ссавців.

Ключові слова: нокаут гена pttg-1, прочесинг глікополімерів, лектинова гістохімія.

\section{О. Ю. Варивода, Е. З. Филяк, А. Д. Луичик, Р. С. Стойка}

Нокаут гена pttg-1 у мышей сопровождается возрастанием уровня экспонирования углеводных детерминант DGalNAc

\section{Резюме}

Цель. Исследовать влияние нокаута гена pttg-1 на гликом некоторых паренхиматозных органов мымей с применением лектиновой гистохимии. Методы. Углеводные детерминанты DGalNAc, DGlcNAc, NeuNAc выявляли с использованием лектинов сои и завязей пшеницы, меченных пероксидазой хрена, с последующей визуализацией диаминобензидином. Тест-объектами служили семенники и почки мышей линии BL6/C57 с нокаутом гена pttg-1 u мылией дикого типа. Возраст животных обеих групп составлял 1 месяи. Результаты. Нокаут гена pttg-1 сопровождается возрастанием экспонирования углеводных детерминант DGalNAc в составе комплекса Гольджи вторичных сперматоцитов, щчеточной каемки почечных трубочек и на люменальной поверхности собирательных протоков. Выводы. Полученные результаты свидетельствуют о том, что отсуствие гена рttg-1 может приводить к изменениям в процессинге углеводсодержащих биополимеров в организме млекопитаюших.

Ключевые слова: нокаут гена pttg-1, прочессинг гликополимеров, лектиновая гистохимия.

\section{REFERENCES}

1. Pei L., Melmed S. Isolation and characterization of a pituitary tumor-transforming gene (PTTG) // Mol. Endocrinol.-1997.11, N 4.-P. 433-441.

2. Zhang X., Horwitz G. A., Prezant T. R., Valentini A., Nakashima M., Bronstein M. D., Melmed S. Structure, expression, and function of human pituitary tumor-transforming gene (PTTG) // Mol. Endocrinol.-1999.-13, N 1.-P. 156-166.

3. Filyak Yu. Z., Filyak O. S., Sushelnytskiy S. I., Stoika R. S. Proteomics of T-lymphocytes from mice lacking pttg gene// Rep. of the Nat. Acad. of Sci. of Ukraine.-2007.-N 5.-P. 173-179.

4. Tfelt-Hansen J., Kanuparthi D., Chattopadhyay N. The emerging role of pituitary tumor transforming gene in tumorigenesis // Clin. Med. Res.-2006.-4, N 2.-P. 130-137.

5. Wang Z., Yu R., Melmed S. Mice lacking pituitary tumor transforming gene show testicular and splenic hypoplasia, thymic hyperplasia, thrombocytopenia, aberrant cell cycle progression, and premature centromere division // Mol. Endocrinol.-2001.15, N 11.-P. 1870-1879.

6. Kanyuka O., Filyak Yu., Sybirna N. Erythrone functional state in mice with the knockout of PTTG gene // Visnyk of Lviv Univ., Ser. Biology.-2011.-N 56.-P. 22-27.

7. Afanasiev S. V., Filyak Yu. Z., Stoika R. S. Influence of pttg-1 gene knockout on autoimmunity development in mice // Stud. Biol.-2011.-5, N 2.-P. 29-36.

8. Bilyy R., Nemesh L., Antonyuk V., Kit Y., Valchuk I., Havryluk A., Chopyak V., Stoika R. Apoptosis-related changes in plasma membrane glycoconjugates of peripheral blood lymphocytes in rheumatoid arthritis // Autoimmunity.-2009.-42, N 4.-P. 334-336.

9. Bilyy R. O., Shkandina T., Tomin A., Munoz L. E., Franz S., Antonyuk V., Kit Y. Y., Zirngibl M., Furnrohr B. G., Janko C., Lauber K., Schiller M., Schett G., Stoika R.S., Herrmann M. Macrophages discriminate glycosylation patterns of apoptotic cell-derived microparticles // J. Biol. Chem.-2012.-287, N 1.P.496-503.

10. Antonyuk V. O. Lectins and their resources.-Lviv: Kvart, 2005.554 p.

11. Lutsyk A. D., Panasiuk E. M., Lutsyk M. D. Lectins in histochemistry.-Lviv: Vyshcha shkola, 1989.-144 p.

12. Zou H., McGarry T. J., Bernal T., Kirschner M. W. Identification of a vertebrate sister chromatid separation inhibitor involved in transformation and tumorigenesis // Science.-1999.-285, N 5426.-P. 418-422.

13. Habibi-Rezaei M., Hosseinipanah S. M., Fazel A. R. Lectin binding characteristics of murine zona pellucid during folliculogenesis: the importance of $\mathrm{N}$-acetyl sugar derivates // J. Sci. Univ. of Tehran.-2008.-33, N 4.-P. 25-31.

14. Amabarova N. O. Rearrangement of rat kidney sialoglycans during postnatal morphogenesis and in streptozotocin-induced diabetic nephropathy // Acta Med. Leopoliensia.-2009.-15, N 2.P. 35-45.

15. Sogomonian E. A., Lutsyk A. D. Peculiarities of histological structure and lectin histochemistry of rat ovary in hypo- and hyperthyroidism // Svit Medytsyny i Biolohiyi.-2009.-2, N 2.P. 116-124. 
Figures to article by Varyvoda O. Yu. et al.


Рис. 1. Порівняльна мікроморфологія звивистих сім'яних канальців мишей дикого типу $(a, b, \partial)$ та мишей 3 нокаутом гена pttg-1 $(\sigma$, 2, e). Спостерігаються дезінтеграція структури, зменшення щільності сперматогенних клітин у сім'яних канальцях мишей pttg-КО (б) у порівнянні з тваринами контрольної групи (a); вибіркова реактивність лектину SBA із зоною комплексу Гольджі вторинних сперматоцитів контрольних ( 8 ) і нокаутних (2) мишей у поєднанні із зростанням насиченості сім'яних канальців останніх SBA-позитивними клітинами; підвищене контурування плазмолеми адлюменального шару сперматогенних клітин мишей контрольної (д) і дослідної (e) груп при обробці лектином WGA. Забарвлення гематоксилін-еозином $(a, \sigma)$, лектинами сої $(6,2)$ і зародків пшениці $(\partial, e)$. Об'єктив $10 \times$, масштабний відрізок 50 мкм
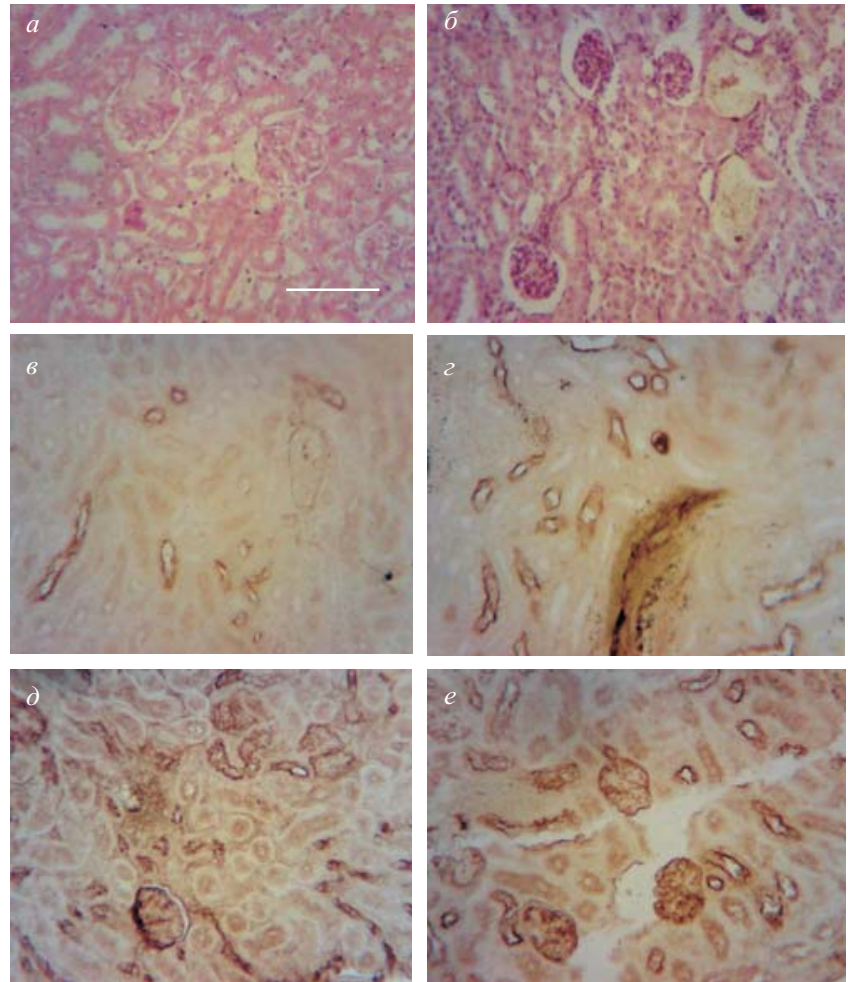

Рис. 2. Кіркова речовина нирки мишей дикого типу $(a, b, \partial)$ і мишей 3 нокаутом гена pttg-1 $(\sigma, 2, e)$. Відзначено збільшення сечового простору, компактизація клубочків ниркових тілець мишей pttg-КО (б) у порівнянні з контролем (a); підвищене експонування рецепторів лектину SBA на люменальній поверхні збірних ниркових проток, у складі щіточкової облямівки нокаутних мишей (2) порівняно $з$ контролем (в); реактивність фільтраційної мембрани ниркових тілець, щіточкової облямівки проксимальних трубочок 3 лектином WGA мишей контрольної ( $\partial$ ) і дослідної групи (e). Забарвлення гематоксилін-еозином $(a, \sigma)$, лектинами сої $(b, z)$ і зародків пшениці $(\partial, e)$. Об'єктив $10 \times$, масштабний відрізок 50 мкм
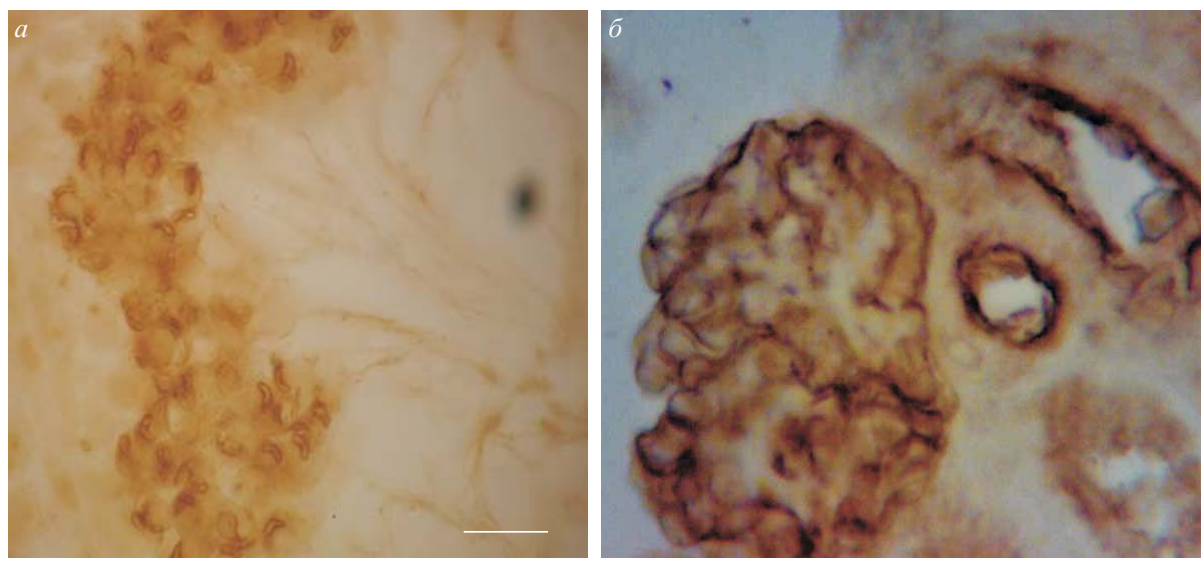

Рис. 3. Зона комплексу Гольджі (подвоєна біомембрана) вторинних сперматоцитів мишей контрольної групи, виявлена з використанням лектину сої $(a)$ та вибіркове маркування фільтраційної мембрани ниркового тільця, щіточкової облямівки ниркових трубочок лектином зародків пшениці (б). Об'єктив $100 \times$, масштабний відрізок 10 мкм 